\title{
Occurrence of tick-borne diseases in domestic dogs in Belém, Pará, Brazil
}

\author{
Ocorrência de doenças transmitidas por carrapatos \\ em cães domésticos em Belém do Pará, Brasil
}

\author{
Mylenna de Cássia Neves Guimarães ${ }^{1^{*}}$ (D), Pâmela Talita de Aguiar e Silva² (D), \\ Thamillys Rayssa Marques Monteiro ${ }^{3}$, Camila de Cássia dos Santos ${ }^{2} \odot$, \\ Jacqueline Corrêa Costa ${ }^{\circledR} \odot$, Keila Feitosa Valente ${ }^{2} \odot$, Barbara Wilka Leal Silva ${ }^{4} \odot$, \\ Alexandre do Rosário Casseb ${ }^{2}{ }^{\circ}$, Livia Medeiros Neves Casseb ${ }^{10}$
}

\begin{abstract}
Tick-borne blood cell pathogens, which are challenging to diagnose, are primarily detected using molecular techniques. Therefore, this study aimed to detect the main infectious agents involved in 50 cases of suspected hemoparasitosis in dogs treated at the Veterinary Hospital Mário Dias Teixeira of the Federal Rural University of the Amazon. Hematological parameters were evaluated, and blood samples were subjected to polymerase chain reaction (PCR) assays for DNA amplification of the following species: Ehrlichia canis, Anaplasma platys, and Babesia canis. The PCR test results indicated that the most prevalent infectious agent was E. canis, present in $12 \%(6 / 50)$ infected animals, followed by $A$. platys and B. canis, present in $8 \%(4 / 50)$ and $2 \%(1 / 50)$ infected animals, respectively. Regarding hematological analysis, the most relevant changes were anemia, lymphopenia, thrombocytopenia, leukocytosis, and leukopenia. The availability of molecular techniques allows the management of the most appropriate treatment to infected animals in a rapid and specific way.
\end{abstract}

KEYWORDS: Ehrlichia; Anaplasma; Babesia; Anemia; Polymerase chain reaction.

\begin{abstract}
RESUMO: Patógenos de células sanguíneas transmitidos por carrapatos, cujo diagnóstico é desafiador, são detectados principalmente por meio de técnicas moleculares. Dessa forma, este estudo teve como objetivo detectar os principais agentes infecciosos envolvidos em 50 casos de suspeita de hemoparasitose em cães atendidos no Hospital Veterinário Mário Dias Teixeira da Universidade Federal Rural da Amazônia. Parâmetros hematológicos foram avaliados e amostras de sangue foram submetidas a ensaios de reação em cadeia da polimerase (PCR) para amplificação de DNA das seguintes espécies: Ehrlichia canis, Anaplasma platys e Babesia canis. Os resultados do teste de PCR indicaram que o agente infeccioso mais prevalente foi $E$. canis, presente em 12\% (6/50) dos animais infectados, seguido por A. platys e B. canis, presente em 8\% (4/50) e 2\% (1/50) animais infectados, respectivamente. Em relação à análise hematológica, as alteraçóes mais relevantes foram anemia, linfopenia, trombocitopenia, leucocitose e leucopenia. A disponibilidade de técnicas moleculares permite o manejo do tratamento mais adequado aos animais infectados de forma rápida e específica.
\end{abstract}

PALAVRAS-CHAVE: Ehrlichia; Anaplasma; Babesia; Anemia; Reação em cadeia da polimerase.

\section{INTRODUCTION}

Ticks are one of the most commonly found arthropods in dogs. In large infestations, animals can present disturbances such as anemia in addition to viral, bacterial, and other protozoal diseases since ticks are carriers of these pathogens (ZHANG et al., 2017; QIU et al., 2018). Some of these pathogens transmitted by ticks use wild, domestic, and livestock animals as their reservoirs; these animals can transmit diseases of a zoonotic importance, representing a potential risk to public health (DANTAS-TORRES; OTRANTO, 2016).

In Brazil, the current tick fauna is composed of 72 species, 47 belong to the Ixodidae family and 25 belong to the Argasidae family (GIANIZELLA et al., 2018). The Ixodidae family includes several species of interest, most of which belong 
to the genera Amblyomma, Dermacentor, Ixodes, Haemaphysalis, and Rhipicephalus (DANTAS-TORRES, 2008).

Some of the commonly reported canine diseases transmitted by these arthropods in veterinary clinical practice include babesiosis, hepatozoonosis, ehrlichiosis, and anaplasmosis, transmitted by the brown tick Rhipicephalus sanguineus sensu lato. Pathogens generally infect blood cells and cause systemic clinical symptoms and severe hematopoietic diseases, which are occasionally life-threatening, such as anemia and thrombocytopenia (SOUSA et al., 2013; KUBO et al., 2015).

Infections caused by obligatory intracellular blood cell pathogens represent an important diagnostic challenge as the clinical signs induced these microorganisms can be similar. In addition, dogs can be infected with more than one infectious agent at the same time in areas where these diseases are endemic (OTRANTO et al., 2009, 2010).

Diagnostic confirmation should include a history of exposure to ticks, compatible clinical signs, physical examination findings, and laboratory confirmation, supported by results of cytological, serological, and molecular tests (OTRANTO et al., 2010). Serological tests are routinely used in clinics, but they do not differentiate active infection from previous exposure; thus, molecular techniques (such as polymerase chain reaction [PCR]) have become the method of choice for detecting pathogens in vertebrates and ticks (AKTAS et al., 2015), distinguishing between species, and revealing the status of current infections (CETINKAYA et al., 2016).

Such infections in companion animals are challenging to diagnose and treat in routine clinical practice due to the complex pathogenesis and wide and nonspecific clinical manifestations in addition to the occurrence of co-infection by more than one infectious agent, potentially exacerbating the severity of the disease (LARA et al., 2020). Therefore, in the present study, we sought to investigate the presence of Ehrlichia canis, Babesia canis, and Anaplasma platys in the blood of domestic dogs treated at the Veterinary Hospital Mário Dias Teixeira of the Federal Rural University of the Amazon (HOVET/UFRA) using molecular methods to evaluate the association between their presence and hematological changes in infected animals.

\section{MATERIAL AND METHODS}

The study was performed in accordance with the fundamental ethical and scientific requirements of the Research Regulatory Guidelines and Norms of the Ethics Committee on the Use of Animals (CEUA/UFRA; protocol number: 001/2016).

\section{Dog samples}

For this study, 50 blood samples received at the Laboratory of Serology and Molecular Biology in 2019 from HOVET/ UFRA were selected from dogs that presented clinic signs suggestive of an infection caused by pathogens transmitted by arthropods (including hematological variations and/or history of tick infestation). The selected samples were from males (32/50) and females (18/50) dogs, including young dogs aged $<2$ years (13/50), adults dogs aged $>2$ years $(27 / 50)$, and $\operatorname{dogs}(10 / 50)$ with no age records.

Blood samples were obtained by puncture of the cephalic or jugular vein in two sterilized microtubes containing the anticoagulant ethylenediaminetetraacetic acid (EDTA), one for the evaluating the complete blood count and the other for PCR assay.

\section{DNA extraction}

DNA was extracted from the samples using a commercial PureLink"' Genomic DNA Mini Kit (Invitrogen, Carlsbad, CA, USA) according to the manufacturer's guidelines. The extracted material was stored at $-20{ }^{\circ} \mathrm{C}$ until PCR analysis.

\section{PCR}

Nested-PCR duplex reactions were used to detect the DNA of $E$. canis and $A$. platys in two stages under thermal conditions described by Rufino et al. (2013). In the initial cycle, a $458 \mathrm{bp}$ fragment was amplified using only the ECC and ECB primers (DAWSON et al., 1994, 1996) specific to the Anaplasmataceae family. The thermal profile of this stage was as follows: $94^{\circ} \mathrm{C}$ for $3 \mathrm{~min}, 94^{\circ} \mathrm{C}$ for $1 \mathrm{~min}, 65^{\circ} \mathrm{C}$ for $1 \mathrm{~min}$, and $72^{\circ} \mathrm{C}$ for $1 \mathrm{~min}$ for a total 35 cycles, with a final extension at $72^{\circ} \mathrm{C}$ for $1 \mathrm{~min}$. The obtained amplicon was subjected to a new amplification cycle using ECAN5 (DAWSON et al., 1996) and HE3 (ANDERSON et al., 1992) primers for $E$. canis, and ApysF and ApysR (RUFINO et al., 2013) specific for $A$. platys. The second round of amplification included 10 cycles of $1 \mathrm{~min}$ at $94^{\circ} \mathrm{C}, 5 \mathrm{~min}$ at $94^{\circ} \mathrm{C}, 1 \mathrm{~min}$ at $62^{\circ} \mathrm{C}$, and $1 \mathrm{~min}$ at $72{ }^{\circ} \mathrm{C}$, followed by 35 cycles of $1 \mathrm{~min}$ at $94^{\circ} \mathrm{C}$, $1 \mathrm{~min}$ at $60^{\circ} \mathrm{C}$, and $1 \mathrm{~min}$ at $72{ }^{\circ} \mathrm{C}$.

In the detection of B. canis, the Bab-f and Babesia common primer sequences, described by Martin et al. (2006) and Kordick et al. (1999), respectively, were used, obtaining a $394 \mathrm{bp}$ fragment. The temperatures for the Babesia amplification process were as follows: $95^{\circ} \mathrm{C}$ for $2 \mathrm{~min}, 94^{\circ} \mathrm{C}$ for $30 \mathrm{~s}, 61^{\circ} \mathrm{C}$ for $30 \mathrm{~s}$, and $72^{\circ} \mathrm{C}$ for $45 \mathrm{~s}$ for a total of 45 cycles, with a final extension at $72{ }^{\circ} \mathrm{C}$ for $10 \mathrm{~min}$.

Sterile water was used as a negative control, and a sample previously identified as positive for each specific pathogen was used as a positive control.

For electrophoretic evaluation, $1 \mu \mathrm{L}$ of blue juice gel loading buffer, $1 \mu \mathrm{L}$ of GelRed ${ }^{\oplus}$, and $4 \mu \mathrm{L}$ of the PCR product were used, which were then applied to $1.5 \%$ agarose gel. The amplified bands were visualized using a UV transilluminator.

\section{Evaluation of hematological findings}

Clinical data from medical records of the dogs were collected using SISVET ${ }^{\oplus}$ program (a software for veterinary clinic 
management) used by the veterinary hospital. Blood count tests were performed for all animals. The reference values used to assess hematological parameters were established as described by Rizzi et al. (2010).

\section{Statistical analysis}

Data were tabulated and analyzed statistically by simple percentage and descriptive statistics using the BioEstat 5.3 program (AYRES et al., 2007). The data were presented graphically using the Microsoft ${ }^{\circledR}$ software package, highlighting the positivity and negativity in PCR assays for E. canis, A. platys, and $B$. canis and the main hematological findings.

\section{RESULTS}

Molecular tests revealed DNA from at least one of the tested pathogens in 22\% (11/50) samples. The results indicated that the most prevalent infectious agent was $E$. canis, present in $12 \%(6 / 50)$ animals, followed by $A$. platys and B. canis in $8 \%$ $(4 / 50)$ and $2 \%(1 / 50)$ animals, respectively.

None of the animals had a tick infestation at the time of the veterinary appointment; however, 26 (52\%) dog owners reported that their dogs had contact with the vector previously. Among these 26 dogs, only 11.5\% (3/26) were positive for the pathogens tested; $7.7 \%(2 / 26)$ were positive for E. canis and $3.8 \%$ were positive for $A$. platys; none of the dogs were positive for $B$. canis.

Regarding hematological analysis, 32 (64\%) dogs presented with anemia, 20 (40\%) had lymphopenia, 25 (50\%) had thrombocytopenia, 13 (26\%) had leukocytosis, and three
(6\%) had leukopenia. Animals in the studied sample did not show any change in the red blood cell parameters, as shown in Figure 1.

There was a considerable variation in the hematological parameters analyzed, as evidenced in Table 1, which presents the standard deviation of hemoglobin and hematocrit levels and red blood cell, platelets, leukocytes, and lymphocytes counts of the animals with positive or negative PCR findings.

Anemia was one of the most frequently observed hematological alterations. This hematological change was found in three $(9.4 \%)$ animals infected with E. canis; it was predominantly s microcytic and normochromic. Regarding dogs positive for $A$. platys and B. canis, 4 (12.5\%) and 1 (3.1\%) dogs were anemic, respectively, with anemia classified as normochromic normocytic.

With regard to platelet alterations, we observed that of the 25 dogs with thrombocytopenia, only six were positive for any one of the infectious agents evaluated on PCR analysis. Among these dogs, in 3 (12\%) DNA of E. canis was detected, in $2(8 \%)$ of $A$. platys and, in $1(4 \%)$ of $B$. canis.

Lymphopenia was observed in 20/50 (40\%) dogs, of which three dogs were positive for E. canis on PCR analysis and the remaining dogs were negative for all the pathogens evaluated on PCR analysis.

\section{DISCUSSION}

The brown tick $R$. sanguineus is a cosmopolitan arthropod that is prevalent throughout the year in tropical and subtropical areas (GALAY et al., 2018). The region of the study, Belém do Pará, has a hot and humid climate (BASTOS et al. 2002),
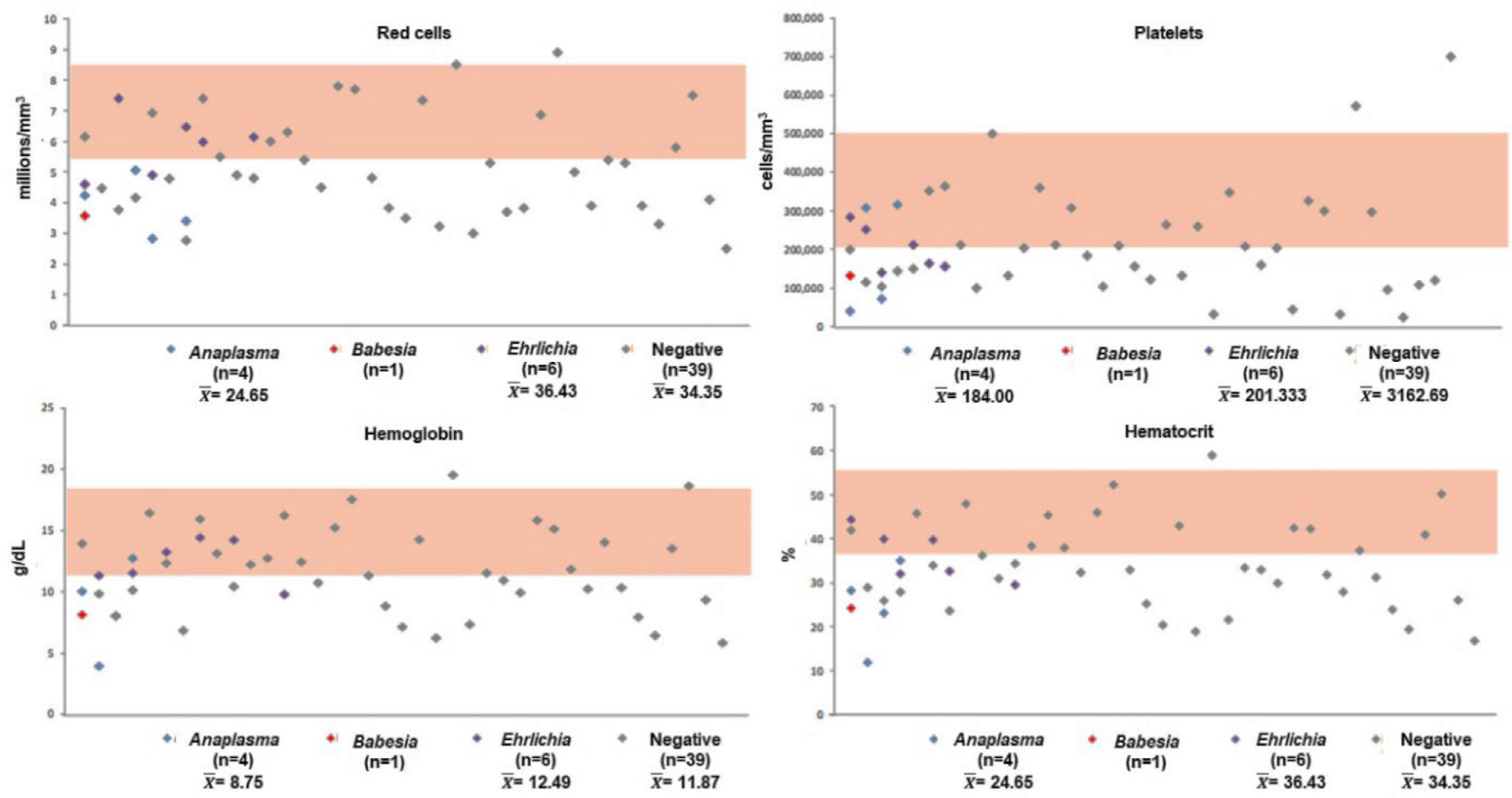

Figure 1. Levels of variation in the number of red blood cells, hemoglobin, hematocrit and the number of platelets. 
Table 1. Result of the statistical analysis of the hematological parameters of dogs tested for Ehrlichia canis and Anaplasma platys in Belém, Pará $(n=50)$.

\begin{tabular}{|c|c|c|c|}
\hline \multirow[t]{2}{*}{ PCR } & \multicolumn{3}{|c|}{$\begin{array}{l}\text { Minimum - Maximum } \\
\underline{X} \pm \text { Standard deviation }\end{array}$} \\
\hline & Negative samples $(n=39)$ & Anaplasma platys $(n=4)$ & Ehrlichia canis $(n=6)$ \\
\hline \multirow{2}{*}{ Red cells } & $2.50-8.90$ & $2.83-5.06$ & $4.60-7.40$ \\
\hline & $5.20 \pm 1.66$ & $3.82 \pm 0.95$ & $5.92 \pm 1.03$ \\
\hline \multirow{2}{*}{ Hemogloblin } & $5.90-19.60$ & $4.00-12.80$ & $9.86-14.50$ \\
\hline & $11.87 \pm 3.57$ & $8.75 \pm 3.71$ & $12.49 \pm 1.84$ \\
\hline \multirow{2}{*}{ Hematocrit } & $5.90-52.30$ & $12.00-35.10$ & $29.60-44.40$ \\
\hline & $32.99 \pm 10.20$ & $24.65 \pm 9.74$ & $36.43 \pm 5.78$ \\
\hline \multirow{2}{*}{ Platelets } & $24.00-760.00$ & $40000.00-316000.00$ & $140.00-284.00$ \\
\hline & $218.46 \pm 152.11$ & $184000.00 \pm 148413.84$ & $201.33 \pm 57.84$ \\
\hline \multirow{2}{*}{ Leukocytes } & $4.00-45.00$ & $4500.00-19400.00$ & $6.00-33.00$ \\
\hline & $16.24 \pm 10.55$ & $10300.00 \pm 6483.31$ & $15.15 \pm 10.29$ \\
\hline \multirow{2}{*}{ Lymphocytes } & $2.00-66.00$ & $6.00-22.00$ & $4.00-33.00$ \\
\hline & $16.54 \pm 14.20$ & $15.25 \pm 7.63$ & $15.17 \pm 10.42$ \\
\hline
\end{tabular}

a favorable climatic condition for the survival and reproduction of ticks.

Although there was no identification of ticks present in infestations, $R$. sanguineus was considered a vector that was the most commonly involved as it is described as a competent vector for the diseases of interest in the study (HII et al., 2015). In addition, most dogs treated at HOVET/ UFRA are bred in urban environments, with no access to areas where wild carnivores and other mammals live, facilitating the occurrence of this arthropod vector (LABRUNA; PEREIRA, 2001; VIEIRA et al., 2018). In contrast, dogs with access to both urban and rural areas in Rio de Janeiro were frequently infested by $R$. sanguineus and A. ovale (PAULINO et al., 2018).

Knowledge of the occurrence of tick-borne diseases in animal species is also extremely important for understanding the risk of human infection (RODRIGUEZ-MORALES et al., 2018), considering that dogs can serve as a source of nutrition for many arthropods that also feed on humans and increase the risk of zoonotic infections (SEO et al., 2020). Six different species of ticks parasitizing humans have been previously identified in the state, with the most frequently being $A$. cajennense and $R$. sanguineus (SERRA-FREIRE, 2020).

Although the dogs had a history of tick infestation, there was a low prevalence of tick-borne infection, even with a high incidence of reported infestation, indicating that this contributes to the maintenance of hemoparasitic infections in the region. Similarly, in a previous study, there was no significant association between tick infestation and the presence of $A$. platys (SILVA G et al., 2012), E. canis (UENO et al., 2009; SOUSA et al., 2010), or B. canis vogeli (SILVA A et al., 2012).
In this context, Soares et al. (2017) stated that the presence of $R$. sanguineus ticks may not be a risk factor for $E$. canis infection in dogs and that the vectorial competence of the tick strain present in the region influences the prevalence of the infectious agent.

Over the past decade, molecular techniques (such as PCRbased methods) have been proven to be useful for the diagnostic confirmation of many diseases transmitted by canine vectors, while serology and cytology have been used historically in epidemiological surveys or for diagnostic purposes (ANDERSSON et al., 2017).

Molecular tests revealed E. canis was the most prevalent infectious agent, present in 12\% (6/50) animals. The prevalence was higher than that reported by Tanikawa et al. (2013) in the state of Paraíba $(3.7 \%$ [4/108] which included animals in a general population independent of the suspected infection), but lower than that reported by Paulino et al. (2018) in Rio de Janeiro (24.8\% [97/390] with animals in a relatively large number sample examined.

A. platys was identified as the second most prevalent infectious agent in the samples analyzed in this study; it was present in $8 \%(4 / 50)$ animals. The prevalence was lower than in similar investigations performed in Rio Grande do Sul (LASTA et al., 2013) (14.07\% [28/199] animals), Paraná (SILVA et al., 2012) (13.67\% [35/256] animals), and Sáo Paulo (SANTOS et al., 2009) (14.9\% [33/221] animals).

Rufino et al. (2013) were the first to report the occurrence of $E$. canis and A. platys infection in dogs in Belém using molecular diagnosis; however, they only evaluated 30 animals. Further, Brandão et al. (2019) reported a detection frequency of $39.4 \%(109 / 276)$ for E. canis and $23.1 \%$ (64/276) for A. platys in the sampled dogs; mixed infection was also detected 
in $13.4 \%$ (37/276) animals. The sample included captured stray animals and pet dogs; it was concluded that stray dogs are the most affected by these parasites.

In this study, B. canis was detected in only one dog. The prevalence is lower than that found by Costa-Junior et al. (2012), who reported a general prevalence rate of $9.9 \%$ (25/252) for B. canis vogeli in the region of Minas Gerais, and by Moraes et al. (2015), who reported a detection rate of 15.7\% (27/172) for Babesia spp. in Pará. Moreover, Galeno et al. (2018) reported similar findings in Maranhão, with $7.69 \%$ (5/65) positivity for B. canis vogeli. It is suggested that very low and fluctuating parasitemia occurs in dogs with babesiosis, possibly analogous to a chronic and asymptomatic natural infection. The ability of PCR to detect parasite DNA in chronically infected animals can be improved by testing on more than one occasion (BOOZER; MACINTIRE, 2003; IRWIN, 2009).

Tick-borne diseases can directly or indirectly affect hematological parameters. Therefore, any animal with a hematological abnormality should be screened for possible underlying parasitic or bacterial infections (LOBETTI, 2004).

Anemia was the most prevalent hematological disorder in the present study. Among 32/50 dogs with anemia, 24 (75\%) did not have DNA of any of the pathogens surveyed.

In dogs with ehrlichiosis, anemia was classified as normochromic microcytic. Thrall et al. (2015) stated that the main cause of microcytosis is iron deficiency, which is generally represented by a decrease in mean corpuscular volume (MCV) (WEISS, 2010). Evidence suggests a direct correlation between anemia in the acute phase of $E$. canis infection and iron metabolism. Bottari et al. (2016) suggested that bacteria use the iron available in the serum for survival, resulting in reduced iron levels in infected animals. A previous study identified a $38-\mathrm{kDa}$ Fbp protein in E. canis that is involved in the acquisition and transport of iron (DOYLE et al., 2005). The reported mechanism may explain the type of anemia found in dogs positive for E. canis in the present study.

Animals with anaplasmosis most commonly presented with presented normocytic and normochromic anemia. Silva (2015) states that this change is common in dogs chronically infected by agents of the family Anaplasmataceae due to the destruction of hematopoietic precursors in the bone marrow by the agent.

Furlanello et al. (2005) described that in canine babesiosis, anemia is initially mild, normocytic, and normochromic; it then becomes macrocytic, hypochromic, and regenerative with disease progresses. Thus, we can conclude that the positive animals were in the initial stage of infection. In addition, in the pathogenesis babesiosis, this change occurs due to the destruction of circulating infected and uninfected erythrocytes by autoantibodies, resulting in intravascular and extravascular hemolysis (SALEM; FARAG, 2014).

Thrombocytopenia is a common finding in infected animals. In both ehrlichiosis and babesiosis, several mechanisms are involved, including the destruction of platelets by immunomodulation (THRALL et al., 2015; CANUTO et al., 2016). Other factors, such as splenic aggregation and sequestration, are involved in the pathogenesis of thrombocytopenia (SHAW et al., 2001). From another perspective, in monoinfection with A. platys, an immune-mediated mechanism occurs after proliferation of the parasite during the initial phase of infection for several cycles (FRENCH; HARVEY, 1993; FERREIRA, et al., 2008).

The occurrence of lymphopenia in dogs with ehrlichiosis corroborates the findings reported by Mendonça et al. (2005) and Bassi et al. (2011). This leukocyte alteration is attributed to the action of corticosteroids and catecholamines released by the adrenal gland during the stress period of acute infection (MENDONÇA et al., 2005).

\section{CONCLUSIONS}

Presence of anemia and thrombocytopenia do not confirm infection with the infectious agents studied; therefore, other diagnostic techniques, such as PCR, are necessary to identify the pathogens (E. canis, B. canis, and A. platys) in animals. The availability of molecular techniques allows the management of the most appropriate treatment to infected animals in a rapid and specific way and, combined with hematological analysis, corroborates to the reliability of the diagnosis.

Therefore, further studies on prevention measures for tick-borne diseases in companion animals should be investigated in the region.

\section{REFERENCES}

AKTAS, M. et al. Molecular detection of tick-borne rickettsial and protozoan pathogens in domestic dogs from Turkey. Parasites \& vectors, v. 8, n. 1, p. 157, 2015.

ANDERSON, B. E. et al. Detection of the etiologic agent of human ehrlichiosis by polymerase chain reaction. Journal of Clinical Microbiology, v. 30, n. 4, p. 775-780, 1992.
ANDERSSON, M. O. et al. Canine tick-borne diseases in pet dogs from Romania. Parasites \& vectors, v. 10, n. 1, p. 1-6, 2017.

AYRES, M.; AYRES Jr, M.; AYRES, D. L.; SANTOS, A. A. S. Bioestat $\mathbf{5 . 0}$ aplicações estatísticas nas áreas das ciências biológicas e médicas. Belém: IDSM, 2007. 364p. 
BASSI, P. B. et al. Aspectos clínicos, epidemiológicos, hematológicos e sorológicos de animais diagnosticados com Ehrlichia canis no Hospital Veterinário de Uberaba-MG. Revista Científica de Medicina Veterinária, v. 9, n. 31, p. 678-680, 2011.

BASTOS, T. X. et al. Aspectos climáticos de Belém nos últimos cem anos. Belém: Embrapa Amazônia Oriental, 2002. 29p.

BOOZER, A. L.; MACINTIRE, Douglass K. Canine babesiosis. The Veterinary clinics of North America. Small Animal Practice, v. 33, ก. 4, p. 885-904, 2003.

BOTTARI, N. B. et al. Iron metabolism and oxidative profile of dogs naturally infected by Ehrlichia canis: Acute and subclinical disease. Microbial pathogenesis, v. 92, p. 26-29, 2016.

BRANDÃO, V. M. D. et al. Molecular detection of Ehrlichia canis and Anaplasma platys in dogs from municipality of Belém, State of Pará, Brazil. Ciência Rural, v. 49, n. 12, 2019.

CANUTO, F. J. C.; MATIAS, A. L. M.; CORTEZ, A. A. Achados hematológicos de cães positivos para babesiose em fortaleza, Ceará. In: CONGRESSO ESTUDANTILDE MEDICINAVETERINÁRIA DA UECE, 4., 2016. Anais... Fortaleza, 2016.

CETINKAYA, H. et al. Serological and molecular investigation of Ehrlichia spp. and Anaplasma spp. in ticks and blood of dogs, in the Thrace Region of Turkey. Ticks and tick-borne diseases, v. 7, n. 5, p. 706-714, 2016.

COSTA-JUNIOR, L. M. et al. Use of a Real Time PCR for detecting subspecies of Babesia canis. Veterinary parasitology, v. 188, ก. 1-2, p. 160-163, 2012.

DANTAS-TORRES, F. The brown dog tick, Rhipicephalus sanguineus (Latreille, 1806) (Acari: Ixodidae): from taxonomy to control. Veterinary parasitology, v. 152, n. 3-4, p. 173-185, 2008.

DANTAS-TORRES, F; OTRANTO, D. Best practices for preventing vector-borne diseases in dogs and humans. Trends in parasitology, v. 32, п. 1, p. 43-55, 2016.

DAWSON, J. E. et al. Susceptibility of white-tailed deer (Odocoileus virginianus) to infection with Ehrlichia chaffeensis, the etiologic agent of human ehrlichiosis. Journal of Clinical Microbiology, v. 32, n. 11, p. 2725-2728, 1994.

DAWSON, J. E. et al. Polymerase chain reaction evidence of Ehrlichia chaffeensis, an etiologic agent of human ehrlichiosis, in dogs from southeast Virginia. American journal of veterinary research, v. 57, п. 8, p. 1175-1179, 1996.

DOYLE, C. K. et al. An immunoreactive 38-kilodalton protein of Ehrlichia canis shares structural homology and iron-binding capacity with the ferric ion-binding protein family. Infect Immun, v. 73, п. 1, 2005.

FERREIRA, R. F. et al. Hematologic parameters in polymerase chain reaction-positive and-negative dogs for Anaplasma platys presenting platelet inclusion bodies. International Journal OfApplied Research In Veterinary Medicine, v. 6, п. 3, p. 185-190, 2008.

FRENCH, T. W.; HARVEY, J. W. Canine infectious cyclic thrombocytopenia (Ehrlichia platys infection in dogs). In: Rickettsial and chlamydial diseases of domestic animals. 1. ed. Oxford: Pergamon, 1993.
FURLANELLO, T. et al. Clinicopathological findings in naturally occurring cases of babesiosis caused by large form Babesia from dogs of northeastern Italy. Veterinary parasitology, v. 134, n. 1-2, p. 77-85, 2005.

GALAY, R. L. et al. Molecular detection of tick-borne pathogens in canine population and Rhipicephalus sanguineus (sensu lato) ticks from southern Metro Manila and Laguna, Philippines. Parasites \& vectors, v. 1l, n. 1, p. 643, 2018.

GALENO, L. S. et al. Detecção molecular de Babesia canis vogeli em cães da cidade de São Luís-MA, Brasil. PUBVET, v. 12, p. 131, 2018.

GIANIZELLA, S. L. et al. Ticks (Acari: Ixodidae) of the state of Amazonas, Brazil. Experimental and Applied Acarology, v. 74, n. 2, p. 177-183, 2018

HII, S. F. et al. Canine tick-borne pathogens and associated risk factors in dogs presenting with and without clinical signs consistent with tick-borne diseases in northern Australia. Australian veterinary journal, v. 93, n. 3, p. 58-66, 2015.

IRWIN, P.J. Canine babesiosis: from molecular taxonomy to control. Parasites \& vectors, v. 2, n. Sl, p. S4, 2009.

KORDICK, S. K. et al. Coinfection with multiple tick-borne pathogens in a Walker Hound kennel in North Carolina. Journal of Clinical Microbiology, v. 37, n. 8, p. 2631-2638, 1999.

KUBO, S. et al. A molecular epidemiological survey of Babesia, Hepatozoon, Ehrlichia and Anaplasma infections of dogs in Japan. Journal of Veterinary Medical Science, p. 15-0079, 2015.

LABRUNA, M. B.; PEREIRA, M. Carrapato em cães no Brasil. Clínica Veterinária, v. 30, p. 24-32, 2001.

LARA, B. et al. Serologic and Molecular Diagnosis of Anaplasma platys and Ehrlichia canis Infection in Dogs in an Endemic Region. Pathogens, v. 9, n. 6, p. 488, 2020.

LOBETTI, R. Hematological changes associated with tick-borne diseases. Proceedings of the World Animal Veterinary Association World Congress, 2004.

MARTIN, A. R. et al. Babesia canis vogeli: a novel PCR for its detection in dogs in Australia. Experimental parasitology, v. 112, ก. 1, p. 63-65, 2006.

MENDONÇA, C. S. et al. Erliquiose canina: alterações hematológicas em cães domésticos naturalmente infectados. Bioscience journal, v. 2l, n. 1, p. 167-174, 2005.

MORAES, P.H. G. et al. Molecular characterization of Babesia vogeli in dogs from Belém, northern Brazil. Genetics Molecular Research, v. 14, n.4, p. 16364-16371, 2015.

OTRANTO, D et al. Managing canine vector-borne diseases of zoonotic concern: part one. Trends in parasitology, v. 25, п. 4, p. 157-163, 2009.

OTRANTO, D. et al. Diagnosis of canine vector-borne diseases in young dogs: a longitudinal study. Journal of clinical microbiology, v. 48, n. 9, p. 3316-3324, 2010.

PAULINO, P. G. et al. Epidemiology of Ehrlichia canis in healthy dogs from the Southeastern region of the state of Rio de Janeiro, Brazil. Preventive veterinary medicine, v. 159, p. 135-142, 2018. 
QIU, Y. et al. Tick-borne haemoparasites and Anaplasmataceae in domestic dogs in Zambia. Ticks and tick-borne diseases, v. 9, ก. 4, p. 988-995, 2018.

RIZZI, T. E.; MEINKOTH, J. H.; CLINKENBEARD, K. D. Normal Hematology of the Dog. In:WEISS, D. J.; WARDROP, K. J. Schalm's Veterinary Hematology. 6. ed. Ames: Weiley-Blackwell Publishing, 2010. p. 799-810.

RODRIGUEZ-MORALES, A. J. et al. Epidemiology of zoonotic tickborne diseases in Latin America: Are we just seeing the tip of the iceberg? Fl000Research, v. 7, 2018.

RUFINO, C. P. et al. Detection of Ehrlichia canis and Anaplasma platys DNA using multiplex PCR. Vector-Borne and Zoonotic Diseases, v. 13, n. 12, p. 846-850, 2013.

SALEM, N. Y.; FARAG, H. S. Clinical, hematologic, and molecular findings in naturally occurring Babesia canis vogeli in Egyptian dogs. Veterinary medicine international, v. 1, 2014.

SEO, M. G.; KWON, O. D.; KWAK, D. Molecular detection and phylogenetic analysis of canine tick-borne pathogens from Korea. Ticks and tick-borne diseases, v. 1l, n. 2, p. 101357, 2020.

SERRA-FREIRE, N. M. Occurrence of ticks (Acari: Ixodidae) on human hosts, in three municipalities in the State of Pará, Brazil. Revista Brasileira de Parasitologia Veterinária, v. 19, n. 3, p. 141-147, 2010.

SILVA, A. B. et al. Detecção molecular de Babesia canis vogeli em cães e em Rhipicephalus sanguineus na mesorregião do oeste maranhense, nordeste brasileiro. Ciência Animal Brasileira, v. 13, п. 3, p. 388-395, 2012.

SILVA, G. C. F. et al. Occurrence of Ehrlichia canis and Anaplasma platys in household dogs from northern Parana. Revista Brasileira de Parasitologia Veterinária, v. 21, n. 4, p. 379-385, 2012.

SILVA, W.A. C. Ocorrência da infecção por Ehrlichia spp e Anaplasma platys em canídeos e felídeos selvagens mantidos em cativeiro no Distrito Federal e Goiás. 2015. 30 f. Dissertação (Mestrado) - Faculdade de Agronomia e Medicina Veterinária, Universidade Federal de Goiás, 2015.

SOARES, R. et al. Molecular survey of Anaplasma platys and Ehrlichia canis in dogs from Campo Grande, Mato Grosso do Sul, Brazil. Anais da Academia Brasileira de Ciências, v. 89, n. l, p. 301-306, 2017.

SOUSA, K. C. M. de et al. Molecular and serological detection of tick-borne pathogens in dogs from an area endemic for Leishmania infantum in Mato Grosso do Sul, Brazil. Revista Brasileira de Parasitologia Veterinária, v. 22, n. 4, p. 525-531, 2013.

SOUSA, V. R. F. et al. Avaliação clínica e molecular de cães com erliquiose. Ciência Rural, v. 40, n. 6, p. 1309-1313, 2010.

TANIKAWA, A. et al. Ehrlichia canis in dogs in a semiarid region of Northeastern Brazil: Serology, molecular detection and associated factors. Research in veterinary science, v.94, n. 3, p. 474-477, 2013.

THRALL, M. A. Morfologia Eritrocitária. In:THRALL, M. A.; WEISER, G.; ALLISON, R. W.; CAMPBELL, T. W. Hematologia e Bioquímica Clínica Veterinária. 2. ed. Rio de Janeiro: Guanabara Koogan, 2015.

UENO, T. E. et al. Ehrlichia canis em cães atendidos em hospital veterinário de Botucatu, Estado de São Paulo, Brasil. Revista Brasileira de Parasitologia Veterinária, v. 18, n. 3, p. 57-61, 2009.

VIEIRA, F.T. et al. Occurrence of ticks in dogs in a hospital population in the state of Espírito Santo, Brazil. Pesquisa Veterinária Brasileira, v. 38, п. 3, p. 519-521, 2018.

WEISS, D. J. Iron and copper deficiencies and disorders of iron metabolism. In:WEISS, D. J.; WARDROP, K. J. Schalm's Veterinary Hematology. 6. ed. Ames: Weiley-Blackwell Publishing, 2010. p. 167-171.

ZHANG, J. et al. Epidemiological survey of ticks and tick-borne pathogens in pet dogs in south-eastern China. Parasite, v. 24, 2017. 